\title{
Impacts of Irradiated Distillers Dried Grains with Soluble (DDGS) as Dietary Supplement on Physiological and Biochemical Aspects of Growing Rabbits
}

\author{
A.M. Abdul Azeem ${ }^{(1) \#}$, U.M. Abdel-Monem ${ }^{(2)}$ and Ashraf M. Mounir ${ }^{(1)}$ \\ (1) Food Irradiation Research Department, National Center for Radiation Research \\ and Technology (NCRRT), Atomic Energy Authority, Cairo, Egypt; (2) Department of \\ Animal Production, Faculty of Agriculture, Zagazig University, Zagazig, Egypt.
}

\begin{abstract}
D ISTILLERS dried grains with soluble (DDGS) are a co-product of ethanol production from starch cereals (mainly corn). Dietary fiber is the sum of carbohydrates and lignin that are resistant to digestion by the small intestine enzymes. DDGS contains approximately 3 times dietary fiber more than corn. Dietary fiber in DDGS consists mainly of insoluble dietary fiber. The present study was conducted to evaluate the effect of gamma $(\gamma)$ irradiation on crude fiber, soluble fiber and non-soluble fiber of irradiated corn DDGs at different doses 0, 10, 20 and $30 \mathrm{kGy}$, and to evaluate the effect of feeding irradiated DDGs for rabbits and their effects on rabbit's performance (body weight, gain weight, feed intake, feed conversion, water intake, rectum temperature and respiration rate), apparent digestibility (dry matter, crude protein, crude fiber and ether extracts), carcass traits (carcass weight, dressing (\%) and prime cuts (\%) and blood biochemistry (AST, ALT, total protein, albumin, globulin, creatinine, total lipids, total cholesterol, and blood urea). Sixty New Zealand White weaned male rabbits of 35 days age were randomly divided to 4 treatment groups of approximately equal average weight $(706 \mathrm{~g})$ with 15 animals each. The first group was fed the basal diet supplemented with $10 \%$ DDGS (nonirradiated) (control), $2^{\text {nd }}, 3^{\text {rd }}$ and $4^{\text {th }}$ groups were fed the control diet supplemented with $10 \%$ irradiated DDGS at 10, 20 and $30 \mathrm{kGy}$, respectively. The obtained results revealed a decrease in crude fiber and increases in soluble fiber and insoluble fiber. The increases were linearly correlated with the increasing irradiation dose. The supplemented irradiated 10\% DDGS up to $30 \mathrm{kGy}$ in the diet of growing rabbits resulted in a significant improvement of body weight, gain weight, feed conversion, the apparent digestibility of dry matter, crude protein, crude fiber, carcass traits (carcass weight, dressing (\%) and prime cuts $(\%)$ ), and the improvement was parallel with increasing the radiation dose. While, feed intake, water intake, rectal temperature, respiration rate, ether extracts digestibility, AST, ALT, total protein, albumin, globulin, total lipids, total cholesterol, creatinine and blood urea were not altered by the treatments. Generally, it can be concluded that radiation processing with $\gamma$-rays improved the soluble and insoluble fiber and the digestibility of DDGS, and that DDGS supplemented diets fed to growing rabbits improved rabbits' growth performance without any deleterious effect on physiological and biochemical attributes.
\end{abstract}

Keywords: Growing rabbits, DDGS, Diet, Digestibility, Biochemical attributes, Gamma radiation.

\section{Introduction}

Dry-grind ethanol (bio-fuel) production is growing in the world market and is expected to continue to increase (Renewable Fuels Association, 2012). Ethanol from grains is a relatively clean and renewable source of energy. Increasing production of ethanol from corn has resulted in large quantities of the residue of grain fermentation, known as distillers dried grains with soluble (DDGS). DDGS are the nutrient rich co-product of the dry-mill ethanol industry; they are the dried residue that remains after the fermentation of corn (or other grains) mash by selected yeasts and enzymes of starch from corn to produce ethanol and carbon dioxide (Butzen \& Haefele, 2008). Although corn is the major grain used in alcohol production, sorghum, barley and

\#Corresponding author email: alyncrrt@yahoo.com

DOI: 10.21608/ejrsa.2018.3184.1042

C2018 National Information and Documentation Center (NIDOC) 
wheat (milo) may also be used. DDGS contains much lower quantities of starch because most of the starch in the corn is converted to ethanol during the fermentation process; only small amounts of starch are present in DDGS. Since, the fiber in corn is not converted to ethanol, the concentration of fiber is high in DDGS than the original grain. The nutrient (protein, fat, fiber, ash and phosphorus) content of DDGS is 2 to 3 times more concentrated than in corn (Stein \& Shurson, 2009). Generally, corn DDGS is utilized as a feed ingredient and recognized as a good source of crude protein (24-29\%), exogenous amino acids, B-group vitamins, mineral compounds and biotin, including high available phosphorus. In addition, DDGS is considered a good source of energy supplement with a valuable source of xanthophyll and linoleic acid (Wang et al., 2007 and Purdum et al., 2014). The nutrient composition of DDGS varies depending on the source of grain and the methods used for ethanol and DDGS production (Min et al., 2008).

Dietary fiber is a key factor which determines nutrient utilization in the diet and more emphasis should be given to routine techniques that identify the nutritional and physiological "quality" of dietary fiber, where the impact of fiber level on digestibility may differ with the properties of the fiber (i.e. soluble vs. insoluble). Total dietary fiber (TDF) is the sum of the dietary carbohydrates that are resistant to digestion by mammalian enzymes in the small intestine, but it can be partially or completely fermented in the hindgut (Institute of Medicine, 2006). According to its solubility, TDF can be divided into: Soluble dietary fibers (SDF), the part of TDF that comprises the non-starch and non-neutral detergent fiber (NDF) polysaccharides, including pectin substances, $\beta$-glucans, fructans and gums (Hall, 2003), and the insoluble dietary and low-digested fiber fractions (IDF) including lignin's, cellulose and hemicelluloses (Gidenne, 2003 and Trocino et al., 2013).

Limitation of the dietary inclusion of DDGS in monogastric animals has been attributed to their high fiber content and to a marginal lysine deficiency associated with heat damage of this amino acid during DDGS manufacture (Stein et al., 2006). Dietary fiber in DDGS consists mainly of insoluble dietary fiber (Urriola et al., 2010) that may increase the water-binding capacity and bulkiness of the diet (Urriola \& Stein, 2010). However, the knowledge available about the effect of dietary inclusion of DDGS on the performance of growing rabbits is still scarce (Soliman et al., 2010; Bernal-Barrágn et al., 2010 and Youssef et al., 2012). Soluble fiber (SF) is an important nutrient that enhances fermentative activity and gut health in rabbits (Maertens et al., 2014).

Food irradiation is a physical -cold process of food preservation by exposing the food to certain amount of ionizing radiation (gamma $(\gamma)$ radiation, or high energy electrons, or X-rays). It has been recognized, approved and endorsed by international organizations (WHO, FAO, IAEA, Codex, etc.) as a reliable and safe method for food shelf-life extension, control of foodborne pathogens, disinfestations of insect pests, etc. It is also used for improving nutritional value and inactivation or removal of anti-nutritional factors in food and feed (Siddhuraju et al., 2002 and Farkas, 2006). It has been reported that treatment of soybean meal and canola meal with $\gamma$ radiation reduced degradation of protein by rumen microorganisms and increased intestinal protein digestibility (Shawrang et al., 2008 and Taghinejad et al., 2009). To our knowledge, there is scarcely information in the literature about the effect of $\gamma$ - irradiation on the characteristics of dietary fiber and the apparent digestibility of irradiated DDGS. Therefore, this study aims to evaluate the possible use of $\gamma$-irradiation processing at different doses to improve the apparent digestibility of DDGS and to investigate its effects as a dietary supplement on New Zealand White weaned male rabbit's performance and nutrients utilization as a monogastric model.

\section{$\underline{\text { Materials and Methods }}$}

The experimental work of the present study was carried out at Food Irradiation Research Department, National Center for Radiation Research and Technology (NCRRT), Atomic Energy Authority, Cairo, Egypt, in cooperation with Faculty of Agriculture, Zagazig University, Zagazig, Egypt.

\section{Radiation processing}

DDGS was obtained from Cairo Poultry Company, packed in well-sealed polyethylene bags. Each bag contained about $5 \mathrm{~kg}$ and was subjected to gamma $(\gamma)$ - radiation from ${ }^{60} \mathrm{Co}$ source at dose levels of $0,10,20$ and $30 \mathrm{kGy}$, as monitored by FWT-60-00 ${ }^{\mathrm{TM}}$ radio-chromic film at room temperature. The radio-chromic dosimeter was 
purchased from Far West Technology, Inc., Goleta, California, USA, (ASTM, 2012 [ISO/ASTM 51275:2012(E)]). The irradiation facility used was Egypt's Mega Gamma-1 Type J-65000 located at the National Center for Radiation Research and Technology (NCRRT), Nasr City, Cairo, Egypt. The non-irradiated and irradiated DDGS $(0,10,20$ and $30 \mathrm{kGy}$ ) samples were stored at $4^{\circ} \mathrm{C}$ until being used. Radiation dose rate during the experimental period was $2.69 \mathrm{kGy} / \mathrm{h}$.

Determination of crude fiber, soluble fiber and insoluble fiber of DDGS

The crude fiber analysis was determined according to AOAC (2012) approved procedure methods of analysis, No. 973.18 using ANKOM 2000 fiber analyzer. The soluble and insoluble fiber was determined using ANKOM dietary fiber analyzer technology method, USA.

\section{Experimental animals}

Sixty New Zealand White (NZW) weaned male rabbits of 35 days age were randomly divided into 4 treatment groups of approximately equal average weight (706g) with 15 animals each.

\section{Experimental design and diets}

Table 1 shows the chemical analysis of DDGS which were analyzed according to AOAC (1990). The first group fed control basal diet supplemented with $10 \%$ DDGS (non-irradiated), $2^{\text {nd }}, 3^{\text {rd }}$ and $4^{\text {th }}$ groups were fed the control basal diet supplemented with $10 \%$ irradiated DDGS at 10, 20 and 30kGy, respectively. Averages of ambient temperature and relative humidity at midday inside the rabbitry building during the experimental period were $19.95^{\circ} \mathrm{C}$ and $70.3 \%$ in the mild period and $27.45^{\circ} \mathrm{C}$ and $75.3 \%$ in the hot period, respectively. The ingredients and nutrient content of basal diet are presented in Table 2.

\section{Management and housing}

All the animals were healthy and clinically free of external and internal parasites and were kept, maintained and treated in adherence to the accepted standards for the humane treatment of animals. All rabbits were kept under the same managerial, hygienic and environmental condition. Rabbits were reared in wire cages as groups, in a well ventilated building, fresh water was automatically available all the time through stainless steel nipples fixed in each cages. All rabbit cages were equipped with feeders and nipples. During the experiment, the total artificial light was about 16h/day. Feed intake was recorded weekly during the whole experimental period. The rabbits were weighed weekly from the beginning till the end of the experiment. Live body weight (g), gain weight (g), feed intake $(\mathrm{g})$ and feed conversion ratio ( $\mathrm{g}$ feed/g gain) were calculated.

The rectal temperature and the respiration rate were measured in rabbits once every two weeks at 9-11a.m. The respiration rate was recorded using a hand counter, which counts the frequency of the flank movement per minute. Internal body temperature was taken using medicine thermometer inserted into the rectum for $2 \mathrm{~min}$ at depth of $2 \mathrm{~cm}$. At the end of the experimental period, three male rabbits from each group were randomly taken for slaughtering. After complete bleeding, pelt, viscera and tail were removed and the carcass and some carcass components were weighted. The blood samples were collected from rabbits during the slaughter and the serum was separated by centrifugation at 3000rpm for 20min and kept in a deep freezer at $-20^{\circ} \mathrm{C}$ until the time of analysis. AST, ALT, total protein, albumin, total lipids, total cholesterol, creatinine and urea concentration in serum were estimated using commercial kits (Bio Merieux, France) according to the procedure outlined by the manufacturer. The globulin concentrations were obtained by subtracting the values of albumin from the corresponding values of total protein.

\section{Digestibility trails}

At the end of the experimental period $(8$ weeks), three rabbits from each treatment were randomly selected and fastened for $24 \mathrm{~h}$. Each rabbit was housed in a metabolic cage and fed on group respective weighed diet for three days to determine the nutrients digestion coefficients and the feeding values of the experimental diets. Feeds and fresh water were offered ad labium. The scattered refused feed was collected and deducted from the amount offered to obtain the quantity of feed consumed. The feces of individual rabbits falling on a tray covered by aluminum foil was quantitatively collected every $24 \mathrm{~h}$, cleaned from hair and scattered feed, dried and weighed. The dried feces from each rabbit were put in screw top glass jar for analysis. Dry matter (DM), crude protein $(\mathrm{CP})$, ether extract (EE) and ash were determined according to AOAC (1990). The nutrients digestibility coefficients and feeding value of the different ingredients were calculated. 
TABLE 1. Chemical analysis of DDGS (As \% DM basis).

\begin{tabular}{lcccccccc}
\hline $\begin{array}{l}\text { Chemical } \\
\text { analysis }\end{array}$ & DM & Ash & EE & CP & CF & Ca & P & $\begin{array}{c}\text { DE } \\
(\mathbf{k c a l} / \mathbf{k g})\end{array}$ \\
\hline DDGS & 90.0 & 4.1 & 9.0 & 27.4 & 9.2 & 0.17 & 0.72 & 2910 \\
\hline DM= Dry matter, EE= Ether extract $\mathrm{CP}=$ Crude protein, $\mathrm{CF}=$ Crude fiber, $\mathrm{Ca}=$ Calcium, $\mathrm{P}=$ Total phosphorus, $\mathrm{DE}=$ Digestible energy.
\end{tabular}

TABLE 2. Composition of experimental basal diet.

\begin{tabular}{lc}
\hline Ingredients & \% \\
\hline Alfalfa hay & 22 \\
Wheat bran & 22 \\
Barley & 19 \\
DDGS & 10 \\
Soybean meal (44\%) & 16 \\
Yellow corn & 6 \\
Molasses & 3 \\
Limestone & 1.1 \\
Sodium chloride & 0.3 \\
Vitamin and minerals premix* & 0.6 \\
Total & 100 \\
Calculated analysis** & --- \\
Crude protein & 18.37 \\
Crude fiber & 11.84 \\
Ether extract & 2.15 \\
Digestible energy (kcal/kg) & 2529 \\
\hline
\end{tabular}

*10.000 IU Vit. A, 900 IU Vit. D3, 2mg Vit. K, 50mg Vit. E, $2 \mathrm{mg}$ Vit. $\mathrm{B}_{1}, 6 \mathrm{mg}$ Vit. $\mathrm{B}_{2}, 2 \mathrm{mg}$ Vit. $\mathrm{B}_{6}, 0.01 \mathrm{mg}$ Vit. $\mathrm{B}_{12}, 20 \mathrm{mg}$ Panathonic acid, 50mg Niacin, $5 \mathrm{mg}$ Folic acid, $1.2 \mathrm{mg}$ Biotin, $12000 \mathrm{mg}$ Choline, $3 \mathrm{mg}$ Copper, $0.2 \mathrm{mg}$ Iodine, $75 \mathrm{mg}$ Iron, 30 $\mathrm{mg}$ Manganese, $70 \mathrm{mg}$ Zinc, $0.1 \mathrm{mg}$ Selenium, $0.1 \mathrm{mg}$ Cobalt and $0.04 \mathrm{mg}$ Magnesium. The basal diet contained of $18.18 \%$ crude protein, $13.43 \%$ crude fiber, $2.29 \%$ ether extract, 2656.00 digestible energy $(\mathrm{kcal} / \mathrm{kg})$.

**Calculated according to NRC (1977) and Cheeke (1987)

\section{Statistical analysis}

The obtained data were statistically analyzed using the SPSS Program (2007). A simple one-way classification analysis was used. Mean differences among treatments were tested by Duncan's multiple range test (Duncan, 1955).

\section{$\underline{\text { Results and Discussion }}$}

Effect of $\gamma$-radiation on crude fiber, soluble fiber and in soluble fiber of DDGS

The statistical analysis of the data in Table 3 demonstrated a significant decrease in crude fiber content of DDGS as a result of exposure to - irradiation treatments. The reduction in the crude fiber content was 2.12, 7.55 and $10.95 \%$ at the dose levels of 10, 20 and $30 \mathrm{kGy}$, respectively. Also, a significant increase in the soluble dietary fiber content of DDGS was observed, and the increase was parallel with increasing the radiation doses.
The results also showed that the insoluble dietary fiber content of DDGS significantly increased, and the increase was proportional with the irradiation doses $(30.82,64.81$ and $66.61 \%$ ) at 10, 20 and $30 \mathrm{kGy}$, respectively. Also from the above data, it was found that the total dietary fiber which is the sum of soluble fiber and insoluble fiber has increased by radiation, and the increase was parallel with increasing the doses of $\gamma$-irradiation used up to $30 \mathrm{kGy}$. The observed decrease in crude fiber content of the irradiated DDGS could be attributed to the depolymerization and delignification characteristics of $\gamma$ - radiation (Sandev \& Karaivanov, 1977). Bhat et al. (2008) found that $\gamma$ - irradiation at various doses $(0,2.5,5,7.5,10,15$ and $30 \mathrm{kGy})$ decreased crude fiber of velvet bean seeds and the decrease was a function of the irradiation doses. Also, Murugan (2015) found that crude fiber, cellulose and acid detergent lignin contents of $\gamma$-irradiated (7 and 14kGy) Brewer's spent grain samples significantly decreased compared to non-treated grains. The dose-dependent decrease in fiber on irradiation has been attributed to depolymerization and delignification of the plant matrix (Bhat et al., 2008). Irradiation could be another explanation for the observed decrease in crude fiber content and the increase in soluble and insoluble fiber contents as this could be attributed to the breaking of the hydrogenic bonds between cellulose and hemicelluloses as well as the degradation of the inter-linkages in lignin structure (Shahbazi et al., 2008). Irradiation of plant raw materials enhances the solubility of the plant cellulose and enhances the ability of this cellulose to undergo acid hydrolysis. This is due to the radiolytic degradation of cellulose (Ershov, 1998). Irradiation itself facilitates the separation of polysaccharides from lignin by breaking up the compartmentalized, crystallized lignocellulosic structure (Woods \& Pikaev, 1994).

\section{Effect of experimental treatments on rabbit's performance}

Live body weight and gain weight $(g)$

Data in Table 4 demonstrates that a significant $(\mathrm{P}<0.05)$ increase was observed in the mean live 
body weight of rabbits fed diets supplemented with $10 \%$ irradiated DDGS for 4 weeks. While, a highly significant $(\mathrm{P}<0.01)$ increase in live body weight of rabbits fed diets supplemented with $10 \%$ irradiated DDGS was observed at the end of the experiment (week 8), and the increase was parallel with increasing the radiation dose. Meanwhile, diets containing $10 \%$ irradiated DDGS significantly $(\mathrm{P}<0.01)$ improved weight gain of rabbits compared to those fed control diet supplemented with non-irradiated DDGS at 4 and 8 weeks and the improvement was parallel to the radiation dose. Bernal-Barrágn et al. (2010) and Youssef et al. (2012) reported that rabbits fed diets supplemented with 10,20 and 30\% of maize DDGS showed improved growth, but did not show any differences in daily weight gains and slaughter weight compared to the control group. In this study, the observed improvement of weight gain in the irradiated DDGS could be due to the $\gamma$-irradiation that caused changes in the complex compound to more simple form (Murugan , 2015).
Feed intake, feed conversion, water intake, rectal temperature and respiration rate

Data tabulated in Table 5 shows no significant $(\mathrm{P}>0.05)$ differences in feed intake and water intake of rabbits fed diet supplemented with irradiated corn DDGS compared to the control group fed diet supplemented with non-irradiated DDGS. However, there was a significant $(\mathrm{P}<0.05)$ difference in feed conversion ratio of rabbits fed diet supplemented with $10 \%$ irradiated corn DDGS compared to their control counterpart. An improvement in feed conversion was observed for those fed diets supplemented with irradiated DDGS and the improvement was proportional with increasing the radiation dose. The best feed conversion was recorded for rabbits fed diets supplemented with 10\% DDGS and subjected to $\gamma$ - ray at $30 \mathrm{kGy}$. This is attributed to the observed higher weight gain and lower feed intake in rabbits fed diets supplemented with the irradiated DDGS. Also, there were no significant differences in rectal temperature and respiration rate among the studied groups.

TABLE 3. Effect of $\gamma$ - irradiation at 10,20 and $30 \mathrm{kGy}$ on crude fiber, soluble dietary fiber, insoluble dietary fiber of DDGS.

\begin{tabular}{lccccc}
\hline \multirow{2}{*}{ Item } & $\begin{array}{c}\text { Control DDGS } \\
\text { (non-irradiated) }\end{array}$ & \multicolumn{3}{c}{ Irradiated DDGS (kGy) } & Sig \\
\cline { 3 - 5 } & $9.40^{\mathrm{a}} \pm 0.03$ & $9.20^{\mathrm{b}} \pm 0.04$ & $8.69^{\mathrm{c}} \pm 0.05$ & $8.37^{\mathrm{d}} \pm 0.04$ & $* *$ \\
\hline Crude fiber \% & $3.60^{\mathrm{b}} \pm 0.80$ & $5.35^{\mathrm{b}} \pm 0.25$ & $7.60^{\mathrm{a}} \pm 0.20$ & $8.10^{\mathrm{a}} \pm 0.30$ & $* *$ \\
Soluble dietary fiber \% & $33.25^{\mathrm{c}} \pm 0.45$ & $43.50^{\mathrm{b}} \pm 0.70$ & $54.80^{\mathrm{a}} \pm 1.00$ & $55.40^{\mathrm{a}} \pm 0.70$ & $* *$ \\
Insoluble dietary fiber \% & $36.85^{\mathrm{c}} \pm 1.30$ & $48.85^{\mathrm{b}} \pm 0.95$ & $62.40^{\mathrm{a}} \pm 1.20$ & $63.50^{\mathrm{a}} \pm 1.00$ & $* *$ \\
Total dietary fiber \% &
\end{tabular}

Means within the same row bearing different letters differ significantly $(\mathrm{P} \leq 0.05)$.

$* *=\mathrm{P}<0.01$, Sig: Significance.

TABLE 4. Body weight and gain weight (0-8 weeks; \pm SE) of growing NZW male rabbits as affected by dietary supplemented of irradiated DDGS at $0,10,20$ and $30 \mathrm{kGy}$.

\begin{tabular}{|c|c|c|c|c|c|}
\hline \multirow{2}{*}{ Item } & \multirow{2}{*}{$\begin{array}{c}\text { Basal diet } \\
\text { supplemented with } \\
10 \% \text { DDGS } \\
\text { (non-irradiated) }\end{array}$} & \multicolumn{3}{|c|}{$\begin{array}{c}\text { Basal diet supplemented with } 10 \% \text { irradiated } \\
\text { DDGS (kGy) }\end{array}$} & \multirow{2}{*}{ Sig } \\
\hline & & 10 & 20 & 30 & \\
\hline $\mathrm{W}_{0}$ & $708.4 \pm 6.1$ & $711.5 \pm 5.9$ & $698.1 \pm 6.2$ & $701.3 \pm 9.8$ & N.S \\
\hline $\mathrm{W}_{4}$ & $1305.5^{\mathrm{d}} \pm 8.1$ & $1403.6^{c} \pm 9.0$ & $1426.5^{b} \pm 8.1$ & $1471.3^{\mathrm{a}} \pm 12.1$ & $*$ \\
\hline $\mathrm{W}_{8}$ & $1673.3^{\mathrm{d}} \pm 10.9$ & $1817.9^{c} \pm 138$ & $1949.7^{\mathrm{b}} \pm 11.1$ & $1999.6^{\mathrm{a}} \pm 16.4$ & $* *$ \\
\hline $\mathrm{G}_{0-4}$ & $597^{\mathfrak{c}} \pm 20.7$ & $692.1^{\mathrm{b}} \pm 28.9$ & $728.4^{\mathrm{a}} \pm 35.4$ & $770^{\mathrm{a}} \pm 78.7$ & $* *$ \\
\hline $\mathrm{G}_{4-8}$ & $367.8^{c} \pm 40.5$ & $414.3^{b} \pm 60.8$ & $523.2^{\mathrm{a}} \pm 0.7$ & $528.5^{\mathrm{a}} \pm 77.4$ & $* *$ \\
\hline $\mathrm{G}_{0-8}$ & $964.9^{\mathrm{c}} \pm 66.7$ & $1106.4^{b} \pm 0.6$ & $1251.6^{a} \pm 50.5$ & $1298.3^{\mathrm{a}} \pm 80.4$ & $* *$ \\
\hline
\end{tabular}

Means within the same row bearing different letters differ significantly $(\mathrm{P} \leq 0.05)$.

$*_{*}^{*}=\mathrm{P}<0.01, *=\mathrm{P}<0.05, \mathrm{~W}$ : week, $\mathrm{w}_{0}$ initial body weight, $\mathrm{w}_{4}$ : Body weight at $4^{\text {th }}$ week, $\mathrm{w}_{8}$ : Body weight at $8^{\text {th }}$ week, $\mathrm{G}$ : $\mathrm{Gain}, \mathrm{G}_{0}-\mathrm{G}_{4}$ : Body weight gain from the beginning of experimental until the $4^{\text {th }}$ week, $\mathrm{G}_{4_{-8}}$ body weight gain from $4^{\text {th }}$ week of the experiment till week $8, \mathrm{G}_{0}-8$ the overall body weight gain (body weight gain from beginning of experimental till the end of the experiment), Sig: Significance, N.S. $=$ Not significant. 
TABLE 5. Feed intake, feed conversion, water intake and water/feed ratio, rectum temperature and respiration rate of growing NZW rabbits as affected by dietary supplemented of irradiated DDGS at 0, 10, 20 and 30 kGy.

\begin{tabular}{|c|c|c|c|c|c|}
\hline \multirow{2}{*}{ Item } & \multirow{2}{*}{$\begin{array}{c}\text { Basal diet } \\
\text { supplemented } \\
\text { with } 10 \% \text { DDGS } \\
\text { (non-irradiated) }\end{array}$} & \multicolumn{3}{|c|}{$\begin{array}{c}\text { Basal diet supplemented with } 10 \% \text { irradiated } \\
\text { DDGS (kGy) }\end{array}$} & \multirow{2}{*}{ Sig } \\
\hline & & 10 & 20 & 30 & \\
\hline Feed intake (g/day) & $97.2^{\mathrm{a}} \pm 4.1$ & $97.1^{\mathrm{a}} \pm 3.9$ & $96.7^{\mathrm{a}} \pm 4.2$ & $98.5^{\mathrm{a}} \pm 3.0$ & N.S \\
\hline Feed conversion (g feed/gain) & $5.65^{\mathrm{a}} \pm 0.08$ & $4.90^{b} \pm 0.04$ & $4.39^{c} \pm 0.07$ & $4.17 \mathrm{~d} \pm 0.05$ & $*$ \\
\hline Water intake (ml/day) & $105.7^{\mathrm{a}} \pm 4.2$ & $100.4^{\mathrm{a}} \pm 4.1$ & $113.5^{\mathrm{a}} \pm 5.1$ & $109.1^{\mathrm{a}} \pm 4.5$ & N.S \\
\hline Water/ feed ratio & 1.08 & 1.03 & 1.15 & 1.13 & - \\
\hline Rectum temperature $(\mathrm{RT})\left({ }^{\circ} \mathrm{C}\right)$ & $39.3^{\mathrm{a}} \pm 0.08$ & $39.1^{\mathrm{a}} \pm 0.06$ & $39.5^{\mathrm{a}} \pm 0.07$ & $39.3^{\mathrm{a}} \pm 0.09$ & N.S \\
\hline $\begin{array}{l}\text { Respiration rate (RR) } \\
\text { (Respirations/minute) }\end{array}$ & $99^{\mathrm{a}} \pm 2.45$ & $100^{\mathrm{a}} \pm 2.71$ & $96^{\mathrm{a}} \pm 2.63$ & $95^{\mathrm{a}} \pm 1.68$ & N.S \\
\hline $\mathrm{RR} / \mathrm{RT}$ & 2.51 & 2.55 & 2.43 & 2.42 & - \\
\hline RT (\%) & 100 & 99.5 & 100.5 & 100 & - \\
\hline RR (\%) & 100 & 101 & 96.9 & 96 & - \\
\hline
\end{tabular}

Means within the same row bearing different letters differ significantly $(\mathrm{P} \leq 0.05)$.

$*=\mathrm{P}<0.05$ and Sig: Significance, N.S $=$ Not significant.

\section{Apparent digestibility}

Table 6 shows a significant $(\mathrm{P}<0.05)$ improvement of the apparent digestibility of dry matter, crude protein and crude fiber of rabbits fed diets supplemented with $10 \%$ irradiated DDGS, while no remarkable effect on ether extracts. The highest significant $(\mathrm{P}<0.05)$ increase in digestibility was observed in rabbits fed diet supplemented with $10 \%$ DDGS irradiated at the highest dose (30kGy) compared to those fed diet supplemented with nonirradiated DDGS.

The herein obtained result concerning the digestibility of dry matter, is in agreement with the study of Shahbazi et al. (2008) who reported that increasing $\gamma$ - irradiation (at 50, 100 and $150 \mathrm{kGy}$ ) had linearly increased the washout fraction of dry matter (DM) and neutral detergent fiber (NDF) of alfalfa hay. Shawraing et al. (2007) reported that $\gamma$ - irradiation at a dose higher than $50 \mathrm{kGy}$ could increase ruminal dry matter degradability of feedstuffs. Where, $\gamma$-irradiation affects the complex bonds and causes the wander-valls power weakens, and consequently results in an extensive degradation of cellulose and increasing the degradability of cell wall constituents (Iller et al., 2002).

The concentration of free radicals and also the number of separated chains from cellulose increase with increasing the irradiation dose (Muto et al., 1995). Irradiation causes formation of carbonyl groups of cellulose in the presence of oxygen that helps cellulose break down (Muto et al., 1995). Furthermore, $\gamma$ - rays lead to the hydrolysis of the glycoside bonds.

For apparent protein digestibility, similar findings were observed by (Zohreh et al., 2017) who found that irradiation at a dose of $30 \mathrm{kGy}$ significantly increased the apparent protein digestibility of cottonseed meal compared to raw meal (non-irradiated). Also, El-Niely (2007) studied the influence of irradiation on in vitro protein digestibility of broad beans irradiated at $2.5,5,10$ and $20 \mathrm{kGy}$, and observed that the in vitro protein digestibility improved by 4.5, 10, 16 and $20 \%$, respectively. Generally, four types of radiation effects on protein are observed: Fragmentation, cross-linkage, aggregation and oxidation by oxygen radicals that are generated in the radiolysis water (Filali-Mouhim et al., 2000). The hydroxyl and superoxide anion radicals that are generated by radiation could modify the proteins molecular properties which result in alteration of proteins by covalent cross-linkages in proteins after irradiation. A higher protein digestibility after irradiation treatment may be due to the increased accessibility of the protein to enzymatic attack. However, this effect could also be due to inactivation of proteinaceous anti-nutritional factors (Van der Poel, 1990). 
Cellulose is the most important source of carbon and energy in ruminant's diet. A plant fiber contains a higher proportion of cellulose and hemicellulose as ligno-cellulosic compound which is the main factor restricting animal's digestion of high-fiber content forage because the animal itself does not produce effective cellulose-hydrolyzing enzymes (Czerkawski, 1986). Each glucose residue of cellulose has inter and intra molecular of two hydrogenic bonds and these bonds stabilize the long and parallel chains of cellulose (Krassig, 1993). $\gamma$ - irradiation affects these glucosidal bonds with modification in hydro glucose ring (Takacs et al., 1999) and causes the wander-valls power weakens (Muto et al., 1995 and Iller et al., 2002). The breaking of hydrogenic bonds, formation of carbonyl groups of cellulose in the presence of oxygen helps cellulose breakdown and results in the degradation of the inter-linkages in lignin structure (Muto et al., 1995).

\section{Carcass traits}

Data in Table 7 shows the results of relative carcass weight, dressing $\%$ and prime cuts $\%$. Statistical analysis revealed a significant $(\mathrm{P}<0.01)$ increase in carcass traits (carcass weight, dressing
(\%) and prime cuts (\%) of rabbits fed diet supplemented with irradiated DDGS at 10, 20 and $30 \mathrm{kGy}$ compared to those fed diet supplemented with non-irradiated DDGS. Carcass weight, dressing $(\%)$ and prime cuts (\%) increased gradually with the escalating radiation dose. This is attributed to the observed improvement of the apparent digestibility of dry matter, crude protein and crude fiber of irradiated DDGS and the consequent improvement of growth performance.

\section{Blood biochemical attributes}

Blood biochemical attributes are used to estimate the health condition of rabbits. The plasma indices are important measures of protein adequacy. The plasma proteins, which are easily obtainable in the animal body, are of value in diagnosis of many diseases (Elamin, 2013). The results of blood chemistry are presented in Table 8. AST and ALT, total protein, albumin, globulin, total lipids, total cholesterol, creatinine and blood urea of rabbits fed control diet supplemented with $10 \%$ (non-irradiated) and those fed diet supplemented with DDGS subjected to $\gamma$ - irradiation at 10,20 and $30 \mathrm{kGy}$ did not show significant differences $(\mathrm{P}<0.05)$ in all studied blood parameters.

TABLE 6. Apparent digestibility of growing NZW rabbits as affected by dietary supplemented of irradiated DDGS at $0,10,20$ and $30 \mathrm{kGy}$

\begin{tabular}{lccccc}
\hline Item & $\begin{array}{c}\text { Basal diet supplemented } \\
\text { with 10\% DDGS } \\
\text { (non-irradiated) }\end{array}$ & \multicolumn{3}{c}{ Basal diet supplemented with 10\% irradiated } \\
DDGS (kGy) & 10 & $\mathbf{2 0}$ & $\mathbf{3 0}$ & Sig \\
\hline Dry matter (DM) & $70.7^{\mathrm{c}} \pm 3.4$ & $73.2^{\mathrm{bc}} \pm 4.5$ & $75.9^{\mathrm{b}} \pm 3.6$ & $79.4^{\mathrm{a}} \pm 6.5^{2}$ & $*$ \\
Crude protein (CP) & $67.2^{\mathrm{c}} \pm 6.1$ & $70.8^{\mathrm{bc}} \pm 5.1$ & $76.0^{\mathrm{b}} \pm 6.2$ & $80.1^{\mathrm{a}} \pm 5.7$ & $*$ \\
Crude fiber (CF) & $59.4^{\mathrm{b}} \pm 2.6$ & $61.4^{\mathrm{b}} \pm 1.7$ & $64.9^{\mathrm{a}} \pm 3.0$ & $65.3^{\mathrm{a}} \pm 1.9$ & $*$ \\
Ether Extract (EE) & $72.0^{\mathrm{a}} \pm 13.1$ & $73.6^{\mathrm{a}} \pm 11.3$ & $74.5^{\mathrm{a}} \pm 16.4$ & $74.8^{\mathrm{a}} \pm 18.0$ & N.S \\
\hline
\end{tabular}

Means within the same row bearing different letters differ significantly ( $\mathrm{P} \leq 0.05)$.

$*=\mathrm{P}<0.05$ and Sig: Significance, N.S $=$ Not significant.

TABLE 7. Carcass traits of growing NZW rabbits as affected by dietary supplemented of irradiated DDGS at 0, 10,20 and $30 \mathrm{kGy}$

\begin{tabular}{lccccc}
\hline & & \multicolumn{2}{c}{ Basal diet supplemented with 10\% irradiated } \\
Item & $\begin{array}{c}\text { Basal diet supplemented with } \\
\text { 10\%DDGs (non-irradiated) }\end{array}$ & $\mathbf{1 0}$ & $\mathbf{2 0}$ & Sig \\
\cline { 3 - 5 } & & $1099.8^{\mathrm{c}} \pm 76$ & $1206.9^{\mathrm{b}} \pm 66$ & $1235.8^{\mathrm{a}} \pm 70$ & $* *$ \\
\hline Carcass weight (g) & $925.3^{\mathrm{d}} \pm 60$ & 60.5 & 61.8 & 61.9 & - \\
Dressing (\%) & 55.3 & 56.7 & 59.5 & 60.2 & - \\
Prime cuts (\%) & 49.1 & & & \\
\hline
\end{tabular}

Means within the same row bearing different letters differ significantly $(\mathrm{P} \leq 0.05)$.

$* *=\mathrm{P}<0.01$, Sig: Significance, N.S $=$ Not significant. 
TABLE 8. Blood attributes $( \pm$ SE) of growing NZW rabbits as affected by dietary supplemented of irradiated DDGS at $0,10,20$ and $30 \mathrm{kGy}$

\begin{tabular}{|c|c|c|c|c|c|}
\hline \multirow{2}{*}{ Item } & \multirow{2}{*}{$\begin{array}{c}\text { Basal diet } \\
\text { supplemented with } \\
10 \% \text { DDGS } \\
\text { (non-irradiated) }\end{array}$} & \multicolumn{3}{|c|}{$\begin{array}{c}\text { Basal diet supplemented with } 10 \% \\
\text { irradiated DDGS (kGy) } \\
\end{array}$} & \multirow{2}{*}{ Sig } \\
\hline & & 10 & 20 & 30 & \\
\hline AST $(g / 100 \mathrm{ml})$ & $15.6^{\mathrm{a}} \pm 2.1$ & $16.1^{\mathrm{a}} \pm 2.5$ & $15.8^{\mathrm{a}} \pm 2.6$ & $15.9^{\mathrm{a}} \pm 2.8$ & N.S \\
\hline ALT $(\mathrm{g} / 100 \mathrm{ml})$ & $10.3^{\mathrm{a}} \pm 1.6$ & $11.00^{\mathrm{a}} \pm 1.4$ & $10.8^{\mathrm{a}} \pm 1.5$ & $11.1^{\mathrm{a}} \pm 1.8$ & N.S \\
\hline Total protein $(\mathrm{g} / 100 \mathrm{ml})$ & $7.7^{\mathrm{a}} \pm 0.4$ & $6.9^{\mathrm{a}} \pm 0.6$ & $6.9^{\mathrm{a}} \pm 0.5$ & $6.8^{\mathrm{a}} \pm 0.3$ & N.S \\
\hline Albumin $(\mathrm{g} / 100 \mathrm{ml})$ & $4.2^{\mathrm{a}} \pm 0.4$ & $4.0^{\mathrm{a}} \pm 0.1$ & $3.9^{\mathrm{a}} \pm 0.2$ & $3.6^{\mathrm{a}} \pm 0.5$ & N.S \\
\hline Globulin $(\mathrm{g} / 100 \mathrm{ml})$ & $3.5^{\mathrm{a}} \pm 02$ & $2.9^{\mathrm{a}} \pm 0.4$ & $3.0^{\mathrm{a}} \pm 0.5$ & $3.2^{\mathrm{a}} \pm 0.3$ & N.S \\
\hline Total lipids (mg/100ml) & $680.3^{\mathrm{a}} \pm 57.5$ & $659.7^{\mathrm{ab}} \pm 62.2$ & $655.1^{\mathrm{b}} \pm 50.1$ & $652.3^{b} \pm 61.6$ & N.S \\
\hline Total cholesterol $(\mathrm{mg} / 100 \mathrm{ml})$ & $191.2^{\mathrm{a}} \pm 40.1$ & $189.1^{\mathrm{a}} \pm 37.7$ & $182.1^{b} \pm 36.9$ & $174.1^{\mathrm{c}} \pm 45.0$ & N.S \\
\hline Creatinine(g/100ml) & $1.4^{\mathrm{a}} \pm 0.7$ & $1.4^{\mathrm{a}} \pm 0.6$ & $1.5^{\mathrm{a}} \pm 0.4^{\mathrm{a}}$ & $1.7^{\mathrm{a}} \pm 0.3$ & N.S \\
\hline Blood urea $(\mathrm{mg} / 100 \mathrm{ml})$ & $20.4^{\mathrm{a}} \pm 3.2$ & $18.8^{\mathrm{a}} \pm 4.0$ & $16.9^{\mathrm{b}} \pm 5.2$ & $18.1^{\mathrm{ab}} \pm 6.1$ & N.S \\
\hline
\end{tabular}

Means within the same row bearing different letters differ significantly Sig: Significance, N.S = Not significant.

\section{Conclusion}

Based on the results obtained from the current study, it could be concluded that $\gamma$ - irradiation (at 10, 20 and $30 \mathrm{kGy}$ ) increased the soluble and insoluble fiber contents of DDGS, increased the apparent digestibility of DDGS and improved the growth performance of rabbits fed irradiated DDGS without any deleterious effects on their physiological and biochemical attributes compared to rabbits fed non-irradiated DDGS.

\section{References}

AOAC (2012) "Official Methods of Analysis", No.973.18 chapter 4, pp.48-49, $19^{\text {th }}$ ed.

AOAC (1990) "Official Methods of Analysis of the Association of Official Agricultural Chemists". Washington DC.

Bhat, R., Sridhar, K.R. and Seena, A. (2008) Nutritional quality evaluation of velvet bean seed (Mucuna pruriens) exposed to gamma irradiation. Int. J. Food Sci. Nutr. 54(4), 261-278.

Bernal-Barrágn, H., Vazqu, E.Z., Pedroso, Y., Nevaro, M.V., Hernandez-Marti-nez, C.A., Cerillo-Soto, M.A., Juare, Z., Reyes, A.S. and Gutierrez-Ornelas, E. (2010) Substitution of sorghum and soybean meal by distillers dried grains with soluble in diets for fattening rabbits. J. Anim. Sci. 88, E suppl. 2.

Butzen, S. and Haefele, D. (2008) Dry-grind Ethanol Production from Corn. Crop Insights. 18, 1-4.
Cheeke, P.R. (1987) "Rabbit Feeding and Nutrition". Academic Press, San Diego, USA.

Czerkawski, J.W. (1986) Chapter XI - Manipulation of rumen fermentation: An introduction to rumen studies. Pergamon Press, Britain, $4^{\text {th }}$ ed., pp.191-204.

Duncan, D.B. (1955) Multiple range and multiple F tests. Biomet. 11, 1

El-Niely, H.F.G. (2007) Effect of radiation processing on anti-nutrients, in vitro protein digestibility and protein efficiency ratio bioassay of legume seeds. Rad. Phy. Chem. 76, 1050-1057.

Elamin, K.M. (2013) Age and sex effects on blood biochemical profile of local rabbits in Sudan. Wayamba J. Anim.Sci. 5, 548-553.

Ershov, B.G. (1998) Radiation-chemical degradation of cellulose and other poly- saccharides. Russ. Chem. Rev. 67, 315-334.

Farkas, J. (2006) Irradiation for better foods. Trends in Food Science and Technology, 17, 148-152.

Filali-Mouhim, A., Audette, M., St-Louis, M., Thauvette, L., Denoroy, L., Penin, F., Cho, Y. and Song, K.B. (2000) Effect of g-irradiation on the molecular properties of BSA and -lactoglobolin. $J$. Biochem. Mol. Biol. 33, 133-137.

Gidenne, T. (2003) Fibers in rabbit feeding for digestive troubles prevention: respective role of low-digested and digestible fibre. Livest. Prod. Sci. 81, 105-117. http://dx.doi.org/10.1016/S0301-6226 (02)00301-9. 
Hall, M.B. (2003) Challenges with nonfiber carbohydrate methods. J. Anim. Sci. 8, 3226-3232.

Iller, E., Kukielka, A., Stupinska, H. and Mikolajczk,W. (2002) Electron-beam stimulation of the reactivity of cellulose pulps for production of derivatives. Radiat. Phys.Chem. 63(3), 395-400.

Institute of Medicine (2006) "Dietary Functional and Total Dietary Fiber". Washington, DC: National Academic Press, pp. 340-421.

Krassig, H.A. (1993) "Cellulose Structure, Accessibility and Reactivity, Polymer Monographs", Huglin M.B. (Ed.), pp. 1-375, Gordon and Breach Science Publisher, ISBN: 2-88124-798- 9, Yverdon, Switzerland.

Maertens, L., Guermah, H. and Trocino, A. (2014) Dehydrated chicory pulp as an alternative soluble fiber source in diets for growing rabbits. World Rabbit Sci. 22, 97-104.

Min, Y.N., Liu, F.Z., Wang, Z., Coto, C., Cerrate, S., Costa, F.P., Yan, F. and Waldroup, P.W. (2008) Evaluation of distillers dried grains with solubles in combination with glycerin in broiler diets. Int. J. Poult. Sci. 7, 646-654.

Muto, N., Takahashi, K. and Yamazaki, H.(1995) Effect of electron beam irradiation on characteristics of paper. Jap.Toppi J. 49(7), 1086-1097.

Murugan, S.S. (2015) Effect of gamma irradiation on chemical composition, fibre fractions of Brewers Spent grains. Indian J. Natur. Sci. 5(29), 42834288.

NRC (1977) "National Research Council. Nutrient Requirements of Rabbits". The $2^{\text {nd }}$ ed. National Academy of Science. Washington, D.C. USA.

Purdum, S., Hanford, K. and Kreifels, B. (2014) Shortterm effects of lower oil dried distillers grains with solubles in laying hen rations. Poult. Sci. 93, 25922595.

Renewable Fuels Association (2012) Ethanol Industry Outlook. Washington, DC, USA. Available at: http://ethanolrfa.3cdn.net/ d4ad995ffb7ae8fbfe_1vm62ypzd.pdf. Accessed December 2012.

Sandev, S. and Karaivanov, I. (1977) The composition and digestibility of irradiated roughage treatment with gamma irradiation. Tierernahr. Fuetterung. 10, 238-242.

Shahbazi, H.R., Sadeghi, A.A., Shawrang, P. and Raisali, G. (2008) Effect of gamma irradiation on ruminal DM and NDF degradation kinetics of alfalfa Hey. Pakistan J. Biol. Sci. 11(8), 1165-1168.

Shawarng, P., Nikkhah, A., Zareh, A., Sadeghi, A.A., Rasiali, G. and Moradi, M. (2007) Effect of gamma irradiation on protein degradation of soybean meal in rumin. Anim. Feed Sci.Technol.134(1), 140-151.

Shawrang, P., Nikkhah, A., Zareh, A., Sadeghi, A. A., Raisali, G. and Moradi, M.(2008) Effects of gamma irradiation on chemical composition and ruminal protein degradation of canola meal. Radiat. Phys. Chem. 77,918-922.

Siddhuraju, P.H., Makkar, P.S. and Becker, K. (2002) The effect of ionizing radiation on antinutritional factors and the nutritional value of plant materials with reference to human and animal food. Food Chem. 78, 187-205.

Soliman, A.Z.M., Ahmed, F.G., El-Manylawi, M.A.F. and Abd-El-Ghany, F.T.F. (2010) Effect of corn distiller's dried grains with soluble (DDGS) on growing rabbit performance. Egypt. J. Rabbit Sci. 20, 31-48.

SPSS/PC Statistics (2007) SPSS/PC Statistics 18.0, SPSS Inc., Chicago, IL, USA.

Stein, H.H., Pedersen, C., Gibson, M.L. and Boersma, M.G. (2006) Amino acid and energy digestibility in ten samples of dried distillers grain with solubles by growing pigs. J. Anim. Sci. 84, 853-860.

Stein, H.H. and Shurson. G.C. (2009) Board-invited review: The use and application of distillers dried grains with solubles in swine diets. J. Anim. Sci. 8 (4), 1292-1303.

Taghinejad, M., Nikkhah, A. Sadeghi, A.A., Raisali1, G. and Chamani, M. (2009) Effects of gamma irradiation on chemical composition, antinutritional factors, ruminal degradation and in vitro protein digestibility of full-fat soybean. Asian-Aust. J. Anim. Sci. 22(4), 534-541.

Takacs, E., Wojnarovits, L., Borsa, J., Foldvari, C.S., Hargittai, P. and Zold, O. (1999) Effect of gamma- 
irradiation on cotton-cellulose. Radiat. Phys. Chem. 55, 663-666.

Trocino, A., García, J., Carabaño, R. and Xiccato, G. (2013) A meta-analysis on the role of soluble fibre in diets for growing rabbits. World Rabbit Sci. 21, 1-15. http://dx.doi.org/10.4995/wrs.2013.1285

Urriola, P.E. and. Stein, H.H. (2010) Effects of distillers dried grains with solubles on amino acid, energy, and fiber digestibility and on hindgut fermentation of dietary fiber in a corn-soybean meal diet fed to growing pigs. J. Anim. Sci. 88, 1454-1462.

Urriola, P.E., Shurson, G.C. and Stein, H.H. (2010) Digestibility of dietary fiber in distillers co-products fed to growing pigs. J. Anim. Sci. 88(7), 2373-2381.

Van der Poel, A.F.B. (1990) Effect of processing on anti-nutritional factors and protein nutritional value of dry beans. Anim. Feed Sci. Technol. 29, 179-208.

Wang, Z., Cerrate, S., Coto, C., Yan, F. and Waldroup,
P.W. (2007) Utilization of distillers dried grains with solubles (DDGS) in broiler diets using a standardized nutrient matrix. Int. J. Poult. Sci. 6(7), 470-477.

Woods, R.J. and Pikaev, A.K. (1994) "Applied Radiation Chemistry-Radiation Processing". Wiley-Interscience, New York, NY.

Youssef, A.W., Abd El-Magid, S.S., Abd El - Gawad, A.H., El -Daly, E.F. and Ali, H.M. (2012) Effects of inclusion of distillers dried grains with soluble (DDGS) on the productive performance of growing rabbits. J. Agr. Environ. Sci. 12(3), 321-326.

Zohreh, B., Somayyeh, S., Mohsen, S., Jamal, F. and Mehdi, B. (2017) Effect of radiation on chemical composition and protein quality of cottonseed meal. Anim. Sci. J. 88(9), 1425-1435

(Received $11 / 3 / 2018$

accepted $30 / 5 / 2018$ ) 


\section{تآثير تثعيع منتجات تقطير الحبوب المجفقة مع الذوائب كمكل غذائي على بعض الجوانب الفسيولوجية و البيوكيميائية للأرانب النامية الفية}

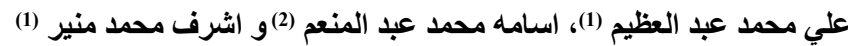

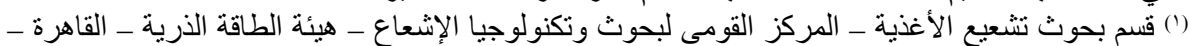

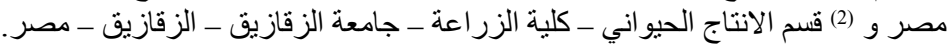

منتجات تقطير الحبوب المجففة مع الذو ائب وهو منتج عرضى يمكن الحصول عليه بعد تخمير الحبوب للحصول

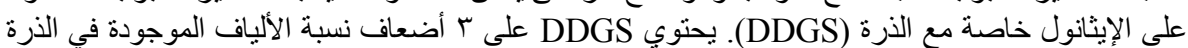

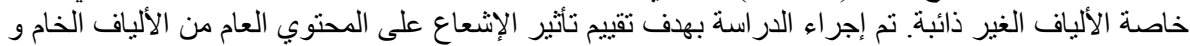

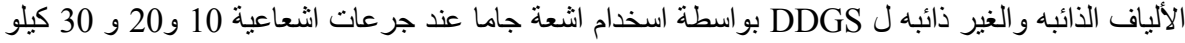

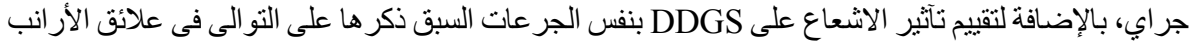

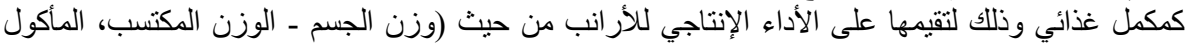

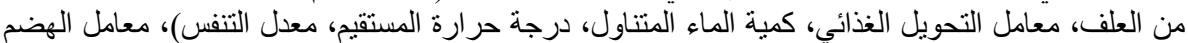

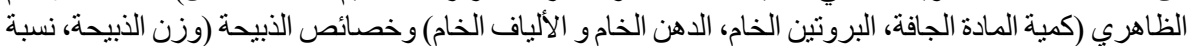

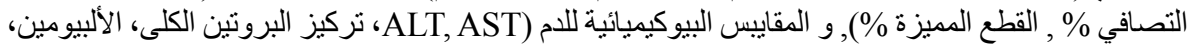

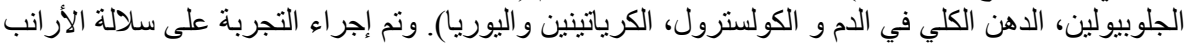

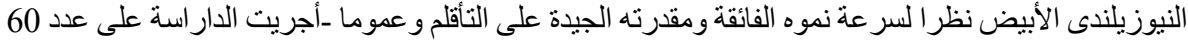

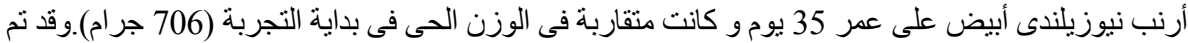

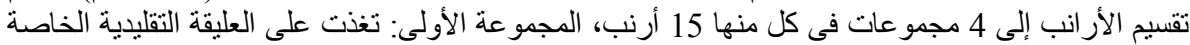

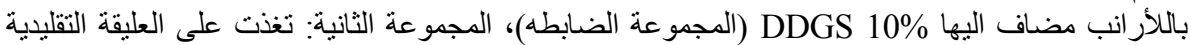

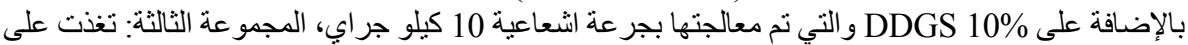

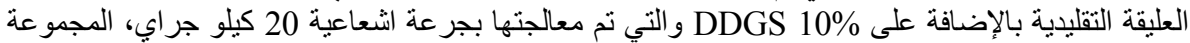

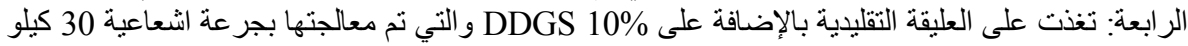

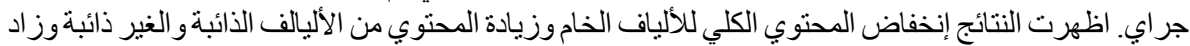

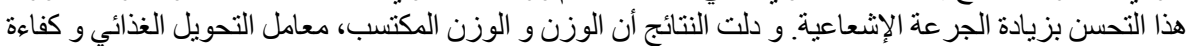

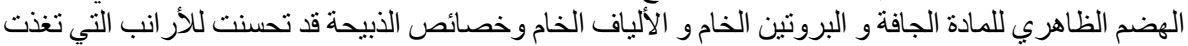

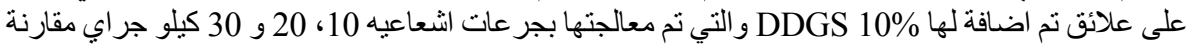

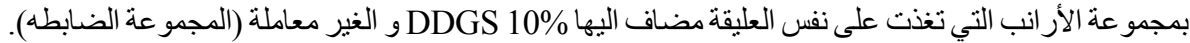

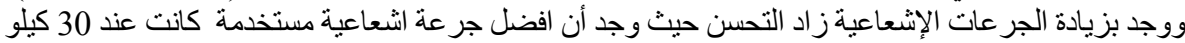

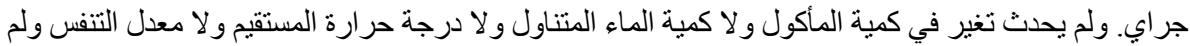

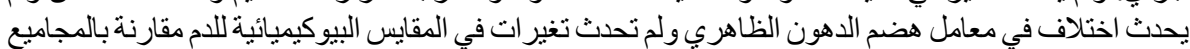

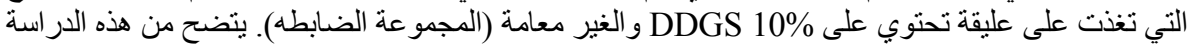

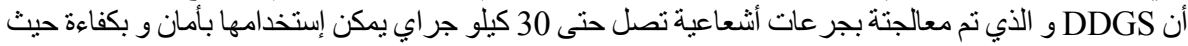

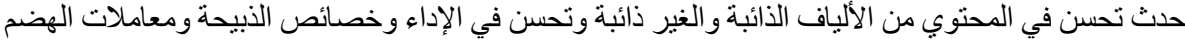
دون حدوث أى تأثير سلبي على المقايس الفسيولوجية و البيوكيميائية للأرانب. 